\title{
The Right to Vote and Restrictions on Crossover Primaries
}

The success of Dan Walker's bid for the Illinois Democratic gubernatorial nomination in 1972 has generally been attributed to the large number of Republican voters who refrained from voting in the Republican primary and, instead, voted for Walker in the Democratic primary. ${ }^{1}$ These crossovers were made possible by the decision of a three judge district court declaring unconstitutional an Illinois law that prohibited a voter from participating in a primary election if he had voted in a primary of another political party within the preceding twenty-three months. ${ }^{2}$

The decision in the Illinois case is only one of several recent decisions holding that state laws restricting participation in primaries are violations of the fourteenth amendment's equal protection clause. ${ }^{3}$

In all these cases, the courts employed a similar rationale. The courts acknowledged that the states have a legitimate interest in preventing primary crossover votes cast only for the purpose of disrupting orderly party functioning and weakening the raided party. But the courts found that this interest is not sufficiently compelling to outweigh the burdens placed on the right to vote and associate by statutes restricting crossovers. Each court found support for its decision in the "new equal protection" and the emphasis on the right to vote in recent Supreme Court decisions. ${ }^{4}$

In Rosario v. Rockefeller, 5 however, the Supreme Court upheld a

1 Chicago Sun Times, March 22, 1972, at 5, col. 1.

2 Pontikes v. Kusper, 345 F. Supp. 1104 (N.D. Ill. 1972), prob. juris. noted, 41 U.S.L.W. 3524 (U.S. Apr. 2, 1973).

3 In Nagler v. Stiles, 343 F. Supp. 415 (D.N.J. 1972), the court held unconstitutional a New Jersey statute allowing persons to vote in the primary of one party only if they had not, in the two preceding annual primaries, voted in the primary of another party. In Yale v. Curvin, 345 F. Supp. 447 (D.R.I. 1972), a similar statute, requiring a twenty-six violative of the equal protection clause. And in Gordon v. Executive Committee of month abstention from voting in primaries before being allowed to cross over was held the Democratic Party, 335 F. Supp. 166 (D.S.G. 1971), the Democratic Party's local executive committee, acting in contravention of a state statute prohibiting voting in the primary of more than one political party in the same year, permitted registered voters to participate in the Democratic mayoral primary even though those voters had voted in a Republican congressional primary several months earlier. The district court held the executive committee's action required by the Constitution.

4 See text and notes at notes $32-47$ infra.

5 93 S. Ct. 1245 (1973). 
New York law that required voters to enroll in the party in whose primary they wished to participate at least thirty days prior to the general election preceding the primary. The effect of the statute was to require the voter to select his party, for purposes of primary voting, from eight to eleven months before the primary contest. The court held that this scheme did not disenfranchise any voters but created only an administrative difficulty, which the voter could avoid by due diligence. The time limitation for enrollment was found to be a reasonable means to deter raiding. The requirement of an insulating general election and an eight to eleven month time delay hindered the development of a deliberate and well-executed plan of raiding. Thus, the legislation, despite its impact on voting and freedom of association, was sustained because the "time limitation for enrollment [was] ... tied to a particularized legitimate purpose, and [was] in no sense invidious or arbitrary." The Court distinguished the New York plan from those that require the voter to abstain from primary participation for a specified time before being permitted to switch parties. While not indicating whether it would sustain restrictions of that type, the Court categorized them critically as those that " 'lock' a voter into an unwanted pre-existing party affiliation from one primary to the next."7

This comment investigates whether the Supreme Court's voting rights decisions require holding unconstitutional state statutes that

6 Id. at 1252 .

7 Id. at 1250. The costs to the sophisticated voter of crossing over under the New York law are little more than in an open primary. The only hindrance to participating in the Democratic primary one year, the Republican the next, and the Liberal the year after, is the administrative inconvenience of reregistering. But in another way the provisions upheld in Rosario are more restrictive than the time limitations on crossing over in those states having "lock in" statutes. Under the New York plan the voter must decide eight months in advance of the primary whether he intends to cross over, while in the "lock in" states if the voter has not voted in any primary in the specified time period, he need not decide in which primary to participate until he is in the voting booth.

Justice Powell, joined by Justices Douglas, Brennan, and Marshall, dissenting, would have found the New York statute unconstitutional because it imposes "substantial and unnecessary" restrictions on the right to vote and associate. $I d$. at 1253. Justice Powell acknowledged that there is a state interest in deterring raiding and that administrative convenience could justify a registration cut-off at some time prior to the primary. He contended, however, that those interests can be protected by less severe measures, suggesting that an enrollment deadline of thirty to sixty days before the primary-" the period most vulnerable to raiding activity"-would be sufficient. Id. at 1257. Moreover, the New York registration requirements apply to those voters not previously affiliated with a party as well as those seeking to change parties. Justice Powell stated that the danger of raiding by previously unaffiliated voters is quite insubstantial and, therefore, does not support the state's argument that deterrence of raiding justifies the statute. Underlying the dissent is a supposition that the effect of party labels and loyalties on voter decisions is minimal. Id, at 1256-57. But see text and note at note 91 infra. 
impose "lock in" restrictions on primary crossovers. While the Supreme Court has indicated that restrictions on the right to vote and political association will be treated with great suspicion, ${ }^{8}$ it has also shown reluctance to interfere in the internal operations of political parties. ${ }^{9}$ The relationship between the restrictions on primary voting and the operations of political parties is an unexplored problem of crucial importance. If the absence of these restrictions seriously hinders the maintenance of strong and viable political parties, then the issue is more complex than the courts have recognized and the state interest sought to be protected is significantly more compelling.

\section{The Courts and the Nominating Process}

\section{A. Status of Primary Elections}

The early attitude of the Supreme Court toward primary elections is found in Newberry v. United States:10 that "[primaries] are in no sense elections for an office, but merely methods by which party adherents agree upon candidates whom they intend to offer and support for ultimate choice by all qualified electors. General provisions touching elections in constitutions or statutes are not necessarily applicable to primaries-the two things are radically different."11 The Court held that article $I$, section 4 of the Constitution, which gives Congress power to regulate elections for the House of Representatives and the Senate, does not empower Congress to limit expenditures of candidates in congressional primaries.

Prior to the 1940's, primaries were considered, in the absence of state regulation, to be functions of the political parties, which were recognized as private associations. Thus, in Grovey $v$. Townsend, ${ }^{12}$ the Court held that the decision of the Convention of the Texas Democratic Party to prohibit all Blacks from participating in the Democratic primary did not constitute state action and, therefore, was not a violation of the fourteenth or fifteenth amendments. The Court had previously held, however, that any state statute aimed at regulating primaries was state action and subject to the restrictions of the fourteenth and fifteenth amendments. ${ }^{13}$

8 See text and notes at notes $32-47$ infra.

8 See text and notes at notes 57-75 infra.

10256 U.S. 232 (1921).

$11 \mathrm{Id}$. at 250.

12295 U.S. 45 (1935).

13 In Nixon v. Herndon, 273 U.S. 536 (1927), a Texas law declaring Blacks ineligible to vote in the Democratic primary was held to violate the fourteenth amendment. In Nixon v. Condon, 286 U.S. 73 (1932), regulations promulgated by the Democratic Party executive committee prohibiting Blacks from voting in the primary were held to violate the 
The judicial view represented by Grovey underwent a radical change beginning with United States $v$. Classic. ${ }^{14}$ In that case, the Supreme Court held that where victory in a congressional primary was tantamount to election due to the one party nature of the state, the primary was an integral part of the election process and the right to participate therein was guaranteed by article I, section 2 of the Constitution. Hence, a state official who willfully altered and falsely counted and certified the results of a Louisiana Democratic primary could be convicted for depriving citizens of a constitutionally protected right. ${ }^{15}$ Four years later, in Smith $v$. Allwright, ${ }^{10}$ the Supreme Court explicitly overruled Grovey and declared the "all-white" primary to be a violation of the fifteenth amendment, even though the restriction had been promulgated by the party convention rather than the state. The Court found that the primary had become an integral part of the electoral process. The state's general election ballot designating primary winners as nominees of the political parties, the restrictions placed on primary participants in nominating independent candidates, and the state regulation of the mechanics of the primaries, indicated that the primary was employed by the state as a crucial part of its election machinery. As such, the primary constituted state action and determination of eligibility to participate was subject to the constitutional restraints of the fourteenth and fifteenth amendments. ${ }^{17}$

In an attempt to circumvent the Court's decision in Allwright, South Carolina repealed all of its laws regulating the operation of primaries and permitted the political parties to take over the entire primary election machinery. In Rice $v$. Elmore, ${ }^{18}$ the Fourth Circuit extended the Allwright rationale, holding that, despite these actions, the "allwhite" primary violated the fourteenth and fifteenth amendments; the importance of the Democratic primary within the electoral system was sufficient in itself to constitute state action.

fourteenth amendment. The regulation was found to be state action when it followed an explicit legislative delegation of power to the committee to set voter qualifications for the primary.

14313 U.S. 299 (1941).

15 The Court overruled a demurrer, which had been sustained by the lower court, to an indictment alleging a violation of sections 19 and 20 of the Federal Criminal Code, now 18 U.S.C. \$\& 24I-42 (1970). Section 19 makes it a criminal offense to "conspire to injure, oppress, threaten, or intimidate any citizen in the free exercise or enjoyment of any right or privilege secured to him by the Constitution or laws of the United States ...." Section 20 prohibits, inter alia, the same offense by one acting "under color of any law."

16321 U.S. 649 (1944).

$17 \mathrm{Id}$. at $663-64$.

18165 F.2d 387 (4th Gir. 1947), cert. denied, 333 U.S. 875 (1948). 
In 1953, the Supreme Court itself extended Allwright. It found unconstitutional a local political association's practice of holding an "allwhite" preprimary for the purpose of selecting a candidate to participate in the regular county Democratic Party primary. ${ }^{19}$ The winner of this preprimary had no special status of any kind recognized by the state, and had to follow procedures for placing his name on the primary ballot identical to those required of all other potential candidates. In his plurality opinion, joined only by Justices Douglas and Burton, Justice Black said:

It is immaterial that the state does not control that part of this elective process which it leaves to the Jaybirds to manage. The Jaybird primary has become an integral part, indeed the only effective part, of the elective process that determines who shall rule and govern in the county. The effect of the whole procedure, Jaybird primary plus Democratic primary plus general election, is to do precisely that which the Fifteenth Amendment forbids-strip Negroes of every vestige of influence in selecting the officials who control the local county matters that intimately touch the daily lives of citizens. ${ }^{20}$

The "white primary cases" seem to establish the view that primaries, as an integral part of the electoral mechanism, constitute state action and are subject to scrutiny under the fourteenth amendment. The "white primary cases," however, all involved restrictions based on race, the most suspect of all classifications. While those restrictions could not be tolerated, it is possible that where the classification is less clearly invidious the courts will be more likely to differentiate between the degree of judicial scrutiny of voting restrictions in primaries and in general elections. ${ }^{21}$

\section{B. Constitutionality of Franchise Restrictions: The Voting Rights Revolution}

The last two decades have seen a judicial and legislative revolution in the abolition of franchise restrictions. ${ }^{22}$ The courts have adopted a new

19 Terry v. Adams, 345 U.S. 461 (1953).

$20 \mathrm{Id}$. at 469-70. For a discussion of the development of the concept of state action and the impact of Terry on that development, see generally Comment, The Strange Career of "State Action" Under the Fifteenth Amendment, 74 YaLE L.J. 1448 (1965).

21 See Casper, Williams v. Rhodes and Public Financing of Political Parties Under the American and German Constitutions, 1969 Sup. Cr. Rev. 271, 278-79 n.31; text and notes at notes 64-67 infra.

22 In addition to the judicial decisions discussed below, Congress enacted the Voting Rights Act of 1965, 42 U.S.C. $\$ \S 1971,1973-73 \mathrm{p}(1970)$ and the 1970 Amendments to the Voting Rights Act, 42 U.S.C. $\S 1973$ (1970). In addition, the twenty-third, twentyfourth, and twenty-sixth amendments to the Constitution had the effect of removing restrictions on the franchise. 
equal protection test, finding unconstitutional many restrictions on the right to vote that previously would have withstood constitutional challenge. ${ }^{23}$ The new equal protection consists of a two-tier approach. When the right asserted is classified as fundamental-voting, ${ }^{24}$ freedom from incarceration, ${ }^{25}$ interstate trave $1,{ }^{26}$ and speech $^{27}$-or when the classification scheme is based on a suspect criterion, most notably race, ${ }^{28}$ the Court will sustain the legislation only when the legislative ends are compelling and the statute is narrowly drawn to cause minimal interference with the protected right. If, on the other hand, the right being urged is not "fundamental" and the classification not suspect, great deferrence to the legislative judgment is mandated. It is sufficient that the classification scheme is rational and reasonably related to a legitimate state objective. ${ }^{29}$

The elevation of the right to vote to a fundamental right subject to the greater scrutiny of the new equal protection is a recent development. It was traditionally thought that the federal Constitution entrusted to the states the authority to determine voter qualifications. ${ }^{30}$ Although the "white primary cases" clearly indicated that the states could not give the franchise to some citizens and deny it to others on the basis of race, when the classification was not based on race the Court was willing to uphold the franchise restriction if it was reasonably related to a legitimate state interest. Thus, as recently as 1959 , the Court upheld a statute conditioning the franchise on passing a literacy test, explicitly noting that the scheme was "neutral" with regard to race. 31

The early 1960's marked a turn from the Court's previous view and the beginning of the "voting rights revolution." In Baker v. Carr 32 and Reynolds $v$. Sims, ${ }^{33}$ while not denying that, in theory, the states could

23 See, e.g., G. Gunther \& N. Dowling, Cases and Materials on Constitutional Law 983-89 (8th ed. 1970); Developments in the Law-Equal Protection, 82 HARv. L. Rev. 1065 (1969).

24 See text and notes at notes $32-47$ infra.

25 E.g., Griffin v. Illinois, 351 U.S. 12 (1956).

26 E.g., Shapiro v. Thompson, 394 U.S. 618 (1969).

27 E.g., Brandenburg v. Ohio, 395 U.S. 444 (1969).

28 See, e.g., Bolling v. Sharpe, 347 U.S. 497 (1954); Korematsu v. United States, 323 U.S. 214,216 (1944). There is some indication that wealth classifications are suspect, even though no case has actually invalidated a law because of its unequal impact on rich and poor. Harper v. Board of Elections, 383 U.S. 663, 666-69 (1966); cf. McDonald v. Board of Election Comm'rs, 394 U.S. 802, 807 (1969). But see Independent School Distr. v. Rodriguez, 93 S. Ct. 1278, 1288-94 (1973).

29 E.g., McGowan v. Maryland, 366 U.S. 420 (1961).

30 E.g., Pope v. Williams, 193 U.S. 621 (1904).

31 Lassiter v. Northampton County Bd. of Elections, 360 U.S. 45 (1959).

32369 U.S. 186 (1962).

33377 U.S. 533 (1964). 
withhold the franchise from all citizens, ${ }^{34}$ the Court made clear that when the franchise is granted the state's burden of justification for treating citizens differently is extremely heavy. In Reynolds the Court relied on the celebrated dicta from Yick Wo v. Hopkins, ${ }^{35}$ that the right to vote is "a fundamental political right, ... preservative of all rights."

In cases following Baker and Reynolds, the Court decided that states could not withhold the franchise from residents stationed in the state by the military, ${ }^{36}$ nor deny participation in the election of county officials to those who lived in a federal enclave within the county. ${ }^{37}$ The Gourt has held unconstitutional state statutes requiring payment of a poll tax as a prerequisite to voting in state elections, ${ }^{38}$ a statute restricting the right to vote in school board elections to parents of children enrolled in the school system and owners and lessees of taxable realty in the school district, ${ }^{39}$ and property requirements for eligibility to participate in referenda on bond issues. ${ }^{40}$ The Court also struck down durational residency requirements of one year in the state and ninety days in the county, ${ }^{41}$ and held that a Texas law requiring excessive filing fees without reasonable alternatives for getting on the ballot was an unconstitutional restriction on the rights of voters seeking to support such nominees. ${ }^{42}$

The reapportionment decisions ${ }^{43}$ are clearly a part of the voting

34 The question of the power of the state to withhold the franchise from all citizens is still, theoretically, open. In Oregon v. Mitchell, 400 U.S. 112 (1970), the Court held that Congress could set qualifications for participation in federal elections, although it was unclear whether such authority was based on the privileges and immunities clause of the fifth amendment, the equal protection clause of the fourteenth amendment, or article I, section 4, article II, section 1, and the "necessary and proper clause" of article I, section 8. The Court also held that Congress could not set qualifications for voting in state and local elections. If a state denied the right to vote to all its citizens, however, it may raise a serious question under the "guarantee of a Republican form of Government" clause in article IV, section 4.

35118 U.S. 356,370 (1886).

36 Carrington v. Rash, 380 U.S. 89 (1965).

37 Evans v. Cornman, 398 U.S. 419 (1970).

38 Harper v. Board of Elections, 383 U.S. 663 (1966).

39 Kramer v. School Distr. No. 15, 395 U.S. 621 (1969).

40 Phoenix v. Kolodziejski, 399 U.S. 204 (1970); Cipriano v. Houma, 395 U.S. 701 (1969). But see Associated Enterprises, Inc. v. Watershed Improvement District, 41 U.S.L.W. 4397 (U.S. March 20, 1973); Salyer Land Co. v. Water Storage District, 41 U.S.L.W. 4390 (U.S. March 20, 1973).

41 Dunn v. Blumstein, 405 U.S. 330 (1972). But see Marston v. Lewis, 41 U.S.L.W. 3498 (U.S. March 19, 1973).

42 Bullock v. Carter, 405 U.S. 134 (1972).

43 E.g., Kirkpatrick v. Preisler, 394 U.S. 526 (1969); Wells v. Rockefeller, 394 U.S. 542 (1969); Avery v. Midland County, 390 U.S. 474 (1968); Reynolds v. Sims, 377 U.S. 533 (1964); Wesbcrry v. Sanders, 376 U.S. 1 (1964). 
rights revolution. ${ }^{44}$ If the states are prohibited from granting the franchise to some citizens and not to others without a compelling state interest, then, according to the Court, it is also impermissible to weight the votes of some citizens more than the votes of others unless a compelling interest for doing so can be demonstrated. On the basis of the one-man, one-vote doctrine enunciated in Wesberry $v$. Sanders, ${ }^{45}$ the Court has indicated that very few of the reasons advanced by the states for unequal apportionment serve to justify deviation from the one-man, one-vote norm. ${ }^{46}$

The Court continued its voting rights revolution in the landmark decision of Williams $v$. Rhodes, ${ }^{47}$ which concerned an Ohio law permitting only nominees of recognized political parties to appear on general election ballots. Under the Ohio scheme, political parties could participate in primary elections only if they had received at least 10 percent of the vote in the previous year's gubernatorial election or had obtained the signatures of at least 15 percent of the electorate on nominating petitions more than nine months before the general election. In the primaries, the parties were required to elect central and county committeemen and delegates to a national convention as well as nominees for office. Candidates for these positions and for nomination could be placed on the primary ballot for one party only if they had not voted in the primary of another party in the four preceding years.

The suit was brought by the American Independent Party, a new party that did not receive the requisite number of signatures until after the early filing date, and by the Socialist Workers Party, an old party that was incapable of obtaining a sufficient number of signatures to qualify. The Court found that, taken together, the restrictions had the effect of making it nearly impossible for any party other than the Democratic or Republican parties to qualify for the general election ballot. Because of this, the Court held that the statutory scheme violated the right to vote and the right of political association of those who would support the nominees of other parties.

The Court's decision in Williams was relied upon heavily in the recent crossover primary cases. In Williams, the interests of the state in limiting the number of candidates on election ballots and maintaining a strong two-party system were found insufficiently compelling to justify

44 See generally Auerbach, The Reapportionment Cases: One Person, One Vote-One Vote, One Value, 1964 Sup. CT. REv. 1.

45376 U.S. 1 (1964).

40 E.g., Wells v. Rockefeller, 394 U.S. 542 (1969); Kirkpatrick v. Preisler, 394 U.S. 526 (1969). But see text and notes at notes 54-55 infra.

47393 U.S. 23 (1968). 
the extensive restrictions on the formation of new parties. Similarly, the courts in the recent primary cases thought that restrictions on crossing over between existing parties have the same potential effect of preventing the nomination of candidates with substantial bipartisan or nonpartisan support. Hence, the courts concluded that the restrictions abridged the right to vote and to associate and that the abridgment was not justified by any sufficiently compelling state interest.

\section{G. Limitations on the Voting Rights Revolution}

There are, however, recent decisions indicating that certain restrictions on the franchise will be sustained even in the face of the voting rights revolution. In Whitcomb $v$. Chavis, ${ }^{48}$ the Supreme Court rejected a challenge to an Indiana law that provided for multimember and single member districting in the state legislature. The plaintiffs, residents of multimember districts, alleged, inter alia, that their votes for defeated candidates gave them no representation, whereas, had their districts been constituted as several single member districts, they would have elected at least one representative. The Court noted that the Constitution guarantees an equal opportunity to participate in the electoral process and an equal "chance of winning," but it does not require an electoral system that maximizes representation of diverse minorities. ${ }^{49}$ The Court found the alleged violation of equal protection to be nothing more than an unavoidable function of an electoral system in which one candidate wins and the other loses.

The importance of Williams $v$. Rhodes ${ }^{50}$ may have been tempered by the Court's subsequent decision in Jenness $v$. Fortson, ${ }^{51}$ which concerned a Georgia law that limited access of candidates to the general election ballot. Under the Georgia statute, only nominees of political parties that had received more than 20 percent of the statewide vote in the preceding gubernatorial or presidential election and candidates that gathered signatures of more than 5 percent of the eligible voters could run in the general election. Although the Court found that the restrictions denied some voters the opportunity of voting for a candidate who best represented their views, it upheld the statute: "There is surely an important state interest in requiring some preliminary showing of a significant modicum of support before printing the name of a political organization's candidate on the ballot-the interest, if no other, in avoiding confusion, deception, and even frus-

48403 U.S. 124 (1971).

$49 \mathrm{Id}$. at $158-60$.

50393 U.S. 23 (1968).

51403 U.S. 431 (1971). 
tration of the democratic process at the general election."52 The Court distinguished Williams $v$. Rhodes on the ground that the Ohio scheme involved more complicated and difficult prerequisites for nomination.

The Supreme Court recently affirmed without opinion a decision of a three judge federal court sustaining the constitutionality of an Ohio statute prohibiting any person from seeking the nomination of a political party if he had participated in the primary of any other political party in the preceding four years. ${ }^{63}$ The opinion of the lower court explicitly held that the maintenance of the integrity of its political parties and the prevention of raiding were sufficient state interests to justify the restrictions that Ohio's statute imposed on the franchise and on the right of political association.

Even in the area of reapportionment the Supreme Court has recently indicated that it is willing to weigh the interests advanced by the state against the restrictions that the state had imposed on first and fourteenth amendment rights.

In Abate v. Mundt, ${ }^{54}$ the Court held that an 11.9 percent deviation from equality in apportioning a county legislature was permissible where the deviation resulted from respect for existing town boundaries and where the county had a century old history of overlapping functions and dual personnel between county administration and the towns. And in Mahan v. Howell, ${ }^{55}$ the Court distinguished between the apportionment of a state legislature and the apportionment of congressional districts. In the latter, the Court said, one-man, one-vote is commanded by article $I$, section 2 of the Constitution and no deviation, except those unavoidable after a good faith effort, is tolerable. But in the apportionment of a bicameral state legislature there is more room for flexibility. In Mahan the Court held that because a percentage variation of 16 percent from the ideal district in Virginia's House of Delegates resulted from a rational state policy respecting boundaries of political subdivisions, the deviation was constitutionally tolerable.

These cases demonstrate that not every restriction on the franchise will be struck down in the name of equal protection. While restrictions that interfere with the right to vote and with the right of political association will be carefully scrutinized, the Supreme Court has recognized that there are compelling state interests in regulating the franchise and limiting the access of candidates to the ballot. ${ }^{56}$ The cases

52 Id. at 442.

63 Lippitt v. Cipollone, 404 U.S. 1032 (1972), aff'g 337 F. Supp. 1405 (N.D. Ohio 1971).

б4 403 U.S. 182 (1971).

55 93 S. Ct. 979 (1973).

50 A leading commentator has suggested that the Supreme Court is changing the 
suggest that the lower courts, in finding the crossover restrictions unconstitutional, failed to give sufficient weight to the interests advanced by the states.

\section{Nonintervention in Political Party Operations}

The argument that primary elections may warrant judicial treatment different from that accorded general elections is strengthened by the doctrine of nonintervention in the internal operation of political parties. ${ }^{57}$ Although political parties are no longer considered purely private associations whose actions fail to constitute state action, nevertheless they are not considered agents of the state in all respects. It has been suggested that much of the nonintervention doctrine had been eroded, ${ }^{58}$ but the recent Supreme Court decision in the companion cases of $O^{\prime}$ Brien v. Brown ${ }^{59}$ and Keane v. National Democratic Party ${ }^{60}$ demonstrate that the nonintervention doctrine may still have some life. Both $O$ 'Brien and Keane concerned challenges to the report of the Credentials Committee of the 1972 Democratic National Convention. Keane involved a challenge to the committee's recommendation not to seat the Illinois delegation elected in the state presidential primary in violation of the "slate making" guidelines adopted by the Democratic Party in the call to the convention. O'Brien involved a challenge to the recommendation to unseat 151 of 271 delegates from California, committed by California law to George McGovern as a result of his victory in the state's "winner-take-all" primary. The committee found the winnertake-all primary to be contrary to the mandate of the 1968 Democratic Convention calling for reform, even though the California rule was not explicitly prohibited by the guidelines implementing those reforms. ${ }^{61}$

"equal protection test" by collapsing the two tiers into one, asking whether there is "an appropriate governmental interest suitably furthered by the differential treatment." Chicago Police Department v. Mosley, 408 U.S. 92, 95 (1972). In Bullock v. Carter, 405 U.S. 134 (1972), the court found the candidate filing fees unconstitutional without speaking in terms of a "compelling interest" and in Rosario v. Rockefeller, 93 Sup. Ct. 1245 (1973) and Marston v. Lewis, 93 Sup. Ct. 1211 (1973), the Court upheld registration requirements without deciding whether the state interest was compelling. Gunther, The Supreme Court, 1971 Term-Foreword: In Search of Evolving Doctrine on a Changing Court: A Model for a Newer Equal Protection, 86 Harv. L. REv. 1, 17-18 (1972).

57 See generally Mitau, Judicial Determination of Political Party Organizational Autonomy, 42 MrNs. L. Rev. 245 (1957).

58 See Note, Judicial Intervention in the Presidential Candidate Selection Process: One Step Backwards, 47 N.Y.U.L. REv. 1185, 1186-1202 (1972).

59409 U.S. 1 (1972).

$60 I d$.

61 See Mandate for Reform: A Report of the Commission on Party Structure and Delegate Selection to the Democratic National Committee (1970). 
The cases came to the Court three days prior to the opening session of the Convention. Citing the pressures of time and finding that the actions of the committee were only recommendations that the Convention might accept or reject, the Court refused to grant writs of certiorari and stayed the judgment of the court of appeals, allowing the Convention to pass upon the recommendations of the Committee. Thus, the possibility of the Convention giving the litigants the relief they sought in court was not foreclosed. The Court acknowledged, however, that the stays "may well preclude any judicial review of the final action of the Democratic National Convention on the recommendation of its Credentials Committee." 62 In granting the stays, the Court considered the probability that the court of appeals erred in holding that the merits of these controversies were appropriate for decision by the federal courts. The majority opinion expressed "grave doubts" about the action of the court of appeals, stating:

No case is cited to us in which any federal court has undertaken to interject itself into the deliberative processes of a national political convention; no holding of this court up to now gives support for judicial intervention in the circumstances presented here, involving as they do, relationships of great delicacy that are essentially political in nature [citation omitted]. Judicial intervention in this area traditionally has been approached with great caution and restraint [citation omitted]. It has been understood since our national political parties first came into being as voluntary associations of individuals that the convention itself is the proper forum for determining intra-party disputes as to which delegates shall be seated. ${ }^{63}$

$O^{\prime} B r i e n$ is in a tradition of judicial reluctance to interfere in the convention process. ${ }^{64}$ Courts have generally refused to apply the oneman, one-vote doctrine to party conventions. ${ }^{05}$ Thus, in Irish $v$.

62109 U.S. at 5.

63 Id. at 4. Justice Marshall, joined by Justice Douglas, issued a vigorous dissent, arguing that the crux of the case was the right to vote and to have one's votes counted in presidential primary elections. Justice Marshall contended that a determination by the convention against the litigants would not be mooted by the termination of the convention and a postconvention determination of the merits would be "a far more serious intrusion into the democratic process" than a current determination of the merits. Id. at 10.

64 See generally Note, Freedom of Association and the Selection of Delegates to National Political Conventions, 56 CorNelr L. REv. 148 (1970); Comment, One Man, One Vote and Selection of Delegates to National Nominating Conventions, 37 U. CH. L. REv. 536 (1970); Note, Constitutional Safeguards in the Selection of Delegates to Presidential Nominating Conventions, 78 YaLE L.J. 1228 (1969).

65 E.g., Bode v. National Democratic Comm., 452 F.2d 1302 (D.C. Cir. 1971); Georgia v. National Democratic Party, 447 F.2d 1271 (D.C. Cir.), cert. denied, 404 U.S. 858 (1971); 
Democratic-Farmer-Labor Party, ${ }^{66}$ the Court specifically noted that because no allegation of racial discrimination was involved, the case was distinguishable from the "white primary cases," and that, as a general matter, judicial intervention in the political process is inappropriate. ${ }^{67}$ In Lynch $v$. Torquato ${ }^{68}$ and in Dahl v. Republican State Committee ${ }^{69}$ lower courts held that elections of Democratic county chairmen and Republican state committeemen were not subject to one-man, one-vote requirements because the elections were inside the realm of political party operations. ${ }^{70}$ In Ray $v$. Blair ${ }^{71}$ cited with approval in O'Brien $v$. Brown, ${ }^{72}$ the Supreme Court sustained the constitutionality of a regulation of the Democratic Party of Alabama that required all candidates in a statewide primary for Presidential Elector, whether or not successful, to take an oath pledging their support for the eventual Democratic presidential nominee. These cases indicate that the courts are more likely to restrain themselves from interfering in the operations of conventions, than from interfering in the regulation of primaries, even though the functions of conventions and primaries in the electoral process are similar. It is apparent, however, that the courts recognize a legitimate interest in maintaining the autonomy of the political parties.

This reluctance to interfere in the operations of political parties may be based on the right of political association. Threats to the right of association usually are found to stem from state actions impairing a group's attempts to organize to pursue a form of expression protected by the first amendment. ${ }^{73}$ For example, in Williams $v$. Rhodes ${ }^{74}$ the Court found that the burden placed by the state on attempts to organize

Irish v. Democrat-Farmer Labor Party, 399 F.2d 119 (8th Gir. 1968). Contra, Maxey v. State Democratic Comm., 319 F. Supp. 673 (W.D. Wash. 1970).

66399 F.2d 119 (8th Cir. 1968).

67 In Gray v. Sanders, 372 U.S. 368 (1963), the Court declared unconstitutional, as a violation of the one-man, one-vote doctrine, the Georgia system of county-unit voting as it was applied in the Democratic senatorial primary. The state, however, did not attempt to justify the use of the system by citing to any unique interest involved in a primary and the Court, after finding state action, was free to treat the case as if it had arisen in a general election context.

68343 F.2d 370 (3d Cir. 1965).

69319 F. Supp. 682 (W.D. Wash.), vacated and remanded on other grounds, 393 U.S. 408 (1970).

70 See also Seergy v. Republican County Comm., 459 F.2d 308 (2d Cir. 1972), in which the court permitted the Republican county central committee to use a voting system for all purposes, except candidate selection, that violated one-man, one-vote.

71343 U.S. 214 (1952).

72409 U.S. at 4.

73 E.g., NAACP v. Button, 371 U.S. 415 (1963); NAACP v. Alabama, 357 U.S. 449 (1958).

74393 U.S. 23 (1968). 
a new political party abridged the right of association. A degree of autonomy for political parties may be justified as an extension of the same reasoning. The organization of an effective political party may be impaired as much by not allowing the party to control its own membership and operation as by the state restricting its membership. A party of radicals that cannot limit its membership to those of like persuasion would immediately cease to be an effective voice for radical change. ${ }^{75}$ This does not mean that political parties must be immune from legislative and judicial regulation. It does indicate, however, that the impact on the autonomy of the political party is a factor that must be considered in deciding the constitutionality of statutes relating to political parties.

In the crossover primary cases, the courts found the more severe "lock in" restrictions on crossovers unconstitutional, relying heavily on the voting rights revolution. But the courts seemed unaware that in the absence of racial classification there may be less justification for treating primaries and general elections as if they were the same. For primaries, while part of the electoral process, are also as much a part of political party operations as conventions. By interfering with the parties' internal operations the courts are restricting the parties' autonomy and may be impairing their ability to perform effectively the functions demanded of them in the political system.

\section{Effects of the Grossover Primary}

In determining the effect of the crossover cases, the crucial question is the impact upon the party system of varying the mode of selection of party nominees. It is possible to place the ways in which a party can select its nominees into seven categories. ${ }^{76}$

1. Multiple Vote Primary. Under this system the potential voter is given the ballots of all parties and is permitted to vote for a nominee from each party for each office. While no state currently sanctions this type of primary, it is the ultimate extension of the doctrine that the right to participate in the nominating process is a corollary of the right to vote.

2. Blanket Primary. Under this system, used only in Washington and Alaska, the voter is permitted to participate in one primary for each office, but can alternate among the various parties. In other words,

75 See text at note 100 infra.

70 For a table stating the type of nominating mechanism in effect in each state for statewide offices, see Council of State Governments, 19 THE Boor of the States, 1972-73 at 29 [hereinafter cited as Book OF THE STATES]. 
the voter can, at the same election, participate in the Democratic primary for governor and the Republican primary for senator. ${ }^{77}$

3. Open Primary. Under this scheme the voter is given the ballots of all parties, but is permitted to mark the ballot of only one. Seven states employ this method of nomination for candidates for statewide office. ${ }^{78}$

4. Closed Primary Based on Oath of Affiliation. The closed primary, in a variety of forms, is the mode of party nomination in forty states. It is based on the theory that party nominating procedures should be limited to party members. The definition of party membership varies and, as a result, it is necessary to differentiate between two types of closed primaries. The less restrictive type merely requires the potential voter to take an oath attesting to his past support or present intention to support the party's nominees as a condition of participation in the party primary. ${ }^{79}$

5. Restrictive Closed Primary. This form of the closed primary imposes a more restrictive definition of party membership and requires that a voter seeking to participate in a primary not have voted in the primary of another political party for a specified period of time. A variation on this form requires a voter to register in the party in whose primary he seeks to vote at a given time prior to the primary. It is, of course, these restrictions that are being attacked in the crossover primary cases. ${ }^{80}$

6. Convention. The convention system is the most common means of nominating candidates without using primaries. States vary considerably on the process for selecting delegates to the convention, but all limit participation in that selection process to party members, variously defined. ${ }^{81}$

7. Slatemaking. Under this system, the party nominees are selected

77 In Green v. Texas, 351 F. Supp. 143 (N.D. Tex. 1972), a voter brought a suit alleging that a blanket primary was required by the Constitution once a state had instituted a primary. The court did not sustain the challenge.

78 Michigan, Minnesota, Montana, North Dakota, Utah, Vermont, and Wisconsin. Book OF THE STATES, supra note 76, at 29.

79 The same court that found the twenty-three month Illinois restriction unconstitutional upheld the statement of affiliation requirement. Pontikes v. Kusper, 345 F. Supp. 1104, 1109-10 (N.D. I11. 1972), prob. juris. noted, 41 U.S.L.W. 3524 (U.S. Apr. 2, 1973). On the types of oaths required, see A. RANNEy \& W. KENDALL, DEMOcRacy AND THE AMERICAN PARTY SYSTEM 206 (1956).

80 See text and notes at notes 2-3 supra.

81 Only one state, Indiana, uses the convention system exclusively for nominations for statewide offices. However, fifteen states use a combination of primaries and conventions to select party nominees. BoOK OF THE STATES, supra note 76, at 29. 
in caucus, the participants in the caucus usually having been selected on the basis of their position in the party hierarchy.

The seven basic nominating patterns can be looked at as a continuum of alternatives arranged in order of the quantum of voter participation permitted in each. But it may be an oversimplification to assume that the greater the degree of voter participation in the nominating process, the more democratic the electoral process, as a whole, will become.

It may be helpful to analyze the ways in which these alternative nominating processes would produce differing results in operation. There are two basic reasons why voters who usually support the nominees of one party would desire to participate in the primary of another party-first, to effectuate the nomination of the candidate who could be defeated most easily by the nominee of the voter's own party, and second, to effectuate the nomination of a candidate whom the voter prefers to the nominee of his own party. Only the voter crossing over with the first intention is generally defined as a "raider." 82 In the crossover primary cases, the courts acknowledged a legitimate state interest in preventing raiding. The effect of raiding can be demonstrated with the use of a hypothetical.

Assume a constituency with 200,000 Democrats, 100,000 Republicans, and a Republican candidate uncontested in a primary. The Democratic primary has three contestants, $A, B$, and $C . A$ and $B$ each have the support of about 40 percent of the Democratic voters; $C$ has the support of the remaining 20 percent. Assume further that, if $A$ or $B$ is the Democratic nominee, he will have the support of his own backers, all the backers of the other, and half of C's backers. Hence, if either $A$ or $B$ is nominated, he will be supported by 90 percent of the Democrats and will win the general election.

Under the slatemaking, convention, or closed primary systems, that would, in all likelihood, be the result. $C$ can be nominated only if Republicans are allowed to participate in the Democratic primary. If the Republican voters entered the Democratic primary for the purpose of raiding, then they would support the Republican nominee in the general election and $C$ might not get sufficient support from the supporters of $A$ and $B$ to win the general election. The differences between the multiple vote, the blanket, and the open primary is the degree to which raiding is facilitated. In the open primary the Republican voters would be willing to cross over to nominate $C$ only if there is no primary on the Republican side in which they would like to 
participate. In the blanket primary, the cost of crossing over is less, since the Republican voter is not forced to forego the opportunity of participating in any contest on the Republican side except the primary for the same office. In the multiple vote primary there is no cost in crossing over, since, even if a Republican candidate for the office was faced with a primary challenge, the Republican voter could exercise his vote in the Republican contest and still cross over to vote for $C$ in the Democratic primary. The closed primary based on the oath of affiliation differs from the open primary in reducing raiding only to the extent that the voter takes the oath seriously, since, as a practical matter, the oath cannot be challenged. It is well established that numerous restrictions in the definition of party membership were instituted in response to raiding in supposedly closed primaries. ${ }^{83}$

It seems clear that widespread raiding would seriously diminish the usefulness of the primary as a decision making process; if raiding were widespread, the political parties would do everything possible to avoid primary contests. In the hypothetical above, $A$ and $B$ would avoid competing in the primary at all costs and if $C$ preferred $A$ or $B$ to the Republican nominee, he too would participate in a compromise to avoid the primary. When the probability of raiding is great, as in the multiple vote and blanket primaries, the probability of the stronger party nominating its strongest candidate and the weaker party having its weakest candidate nominated by raiders becomes a real threat. The result may be that the primary of the stronger party becomes the most crucial phase of the election process. ${ }^{84}$

The argument for permitting crossovers is based upon the alternative

83 The restrictions in New Jersey and Illinois, which were successfully challenged in Nagler v. Stiles, 343 F. Supp. 415 (D.N.J. 1972), and Pontikes v. Kusper, 345 F. Supp. 1104 (N.D. Ill. 1972), prob. juris. noted, 41 U.S.L.W. 3524 (U.S. Apr. 2, 1973) respectively, were enacted after several urban political bosses managed to control not only the nominations of their own parties, but those of the opposing parties as well, by convincing enough of their Democratic partisans to vote in the closed Republican primaries. Lest one be tempted to dismiss the practice to those states with a reputation for political chicanery, in Colorado in 1930 and in South Dakota in 1922 Democrats participated in the Republican primary for the purpose of nominating the weakest Republican candidate. In Minnesota in 1938, the Republicans entered the Farmer-Labor Party primary to bring about the defeat in the primary of the incumbent governor. Berdahl, Party Membership in the United States, 36 AM. PoL. ScI. REv. 16, 41-50 (1942). See also A. RANNEY \& W. KENDALL, supra note 79, at 209-11.

84 The turnout in primary elections is generally substantially lower than in general elections, even in those cases in which the primary is known to be more important than the general election. In the solidly Democratic South from 1928-1948, when victory in the Democratic primary was tantamount to election, the turnout was 10 percent higher in the general election. C. Ewing, Prmary Elections in the South: A StUdy IN UNIPARTY PoLITICs 104-05 (1953). 
supposition that the motive for crossing over is not to nominate the weakest candidate, but to support a candidate that the voter prefers to any other candidate, including those of his own party ${ }^{85}$ Given that assumption, in the hypothetical discussed above, those Republicans who would vote for $C$ in the Democratic primary would support him in the general election as well and would support the Republican candidate only if $A$ or $B$ was the Democratic nominee. Assuming that $C$, under these conditions, is the first choice of 50 percent of the Republicans and retains the support of 20 percent of the Democrats, he would win a Democratic primary that permitted crossovers as long as both $A$ and $B$ remained candidates. $C$ 's victory in the primary would result in a general election between the third and fourth choices of a majority of the voters. If it is assumed that $A$ would prefer $B$ to $C$ and $B$ would prefer $A$ to $C$, there exists an incentive for them to compromise so as to avoid a primary contest between themselves.

Those supporting the crossover primary in some form would counter with an alternative hypothetical: a Democratic primary between $A$ and $B-A$ having the support of 60 percent of the Democrats and $B$ having the support of 40 percent. The Republican nominee, who is not being contested for nomination, is supported by 60 percent of the Republicans, while the other 40 percent support $B$. Assuming that there are an equal number of Democrats and Republicans, under a primary system permitting crossovers, $B$ would emerge as the Democratic nominee and subsequently win the general election. But under a primary system prohibiting crossovers, the general election would be between $A$ and the Republican nominee, while $B$, the candidate with the greatest support, would not even be nominated. To the argument that $B$ could always run as an independent in the general election, it might be responded that, without the Democratic nomination, $B$ could not win, since those Democratic voters who favored him in the primary would prefer to support the nominee of the party to $B$ 's independent candidacy. This, however, may well be the strongest argument against allowing the crossover primary. For if those voters who favored $B$ in the primary support $A$ in the three-way general election, it is an indication that remaining a part of the basic coalition of the Democratic Party is more important to them than the election of $B$. It is, in essence, a demonstration that the primary is an intracoalitional event. Party members are attempting to resolve differences within their coalition while intending to remain as a single coalition in the general election. The obvious result is that the party will be forced to resolve its intra-

85 See Rosario v. Rockefeller, 93 S. Ct. 1245, 1255-56 (1973) (dissenting opinion). 
coalitional disputes in some manner before the primary if the primary, because crossovers are allowed, ceases to be an intracoalitional event. Thus, as in the situation described above, $A$ and $B$ will compromise in advance to avoid a primary fight, since the primary will have become a contest between coalitions and it is imperative to have the coalition united prior to the primary in order to win. In a sense, the primary will merely have replaced the general election and a convention or a preprimary of some sort will of necessity replace the primary.

These hypotheticals suggest that in the crossover primary cases the courts may have lost sight of a crucial fact-that the most important function of political parties in the American political system is to aggregate interests and to create coalitions. A political party is, by definition, a group that seeks power. The traditional distinction between a party and an interest group is that the former seeks to govern, while the latter seeks to advance interests and to influence policies. ${ }^{86}$ An interest group is successful when a bill that it has promoted is enacted or when its influence causes the nomination of candidates receptive to its policies. A party is successful only when it gains the reins of government. In American politics the vehicle for attaining power is the election process. Hence, the political parties are the contestants of elections. In order to be successful the parties must create coalitions, and the recruitment of candidates and the mobilization of voters are parts of the process of coalition building. ${ }^{87}$

In a society in which voters are concerned with only a single issue, presenting only two possible solutions, the existence of political parties would be superfluous. An election would be a contest between those who favored one resolution of the issue and those who favored the only alternative, and the side with the most adherents would win. At all subsequent elections the same side would win unless enough voters changed their minds to alter the power balance. In a pluralistic society, however, the need for a coalition maker becomes apparent. Where one voter favors abortion, federal aid to education, and increased defense spending, while another favors gun control, farm subsidies, and legalization of marijuana, the role of political parties increases in importance. In the absence of parties, each interest group would put forward its own candidate whose single major concern would be the policy advocated by the interest group. Each voter would be forced to decide which of the many issues concerning him is most important and align himself with the nominee of the interest group supporting his position on that issue.

86 See, e.g., V.O. Key Politics, Parties, and Pressure Groups 163-65 (5th ed. 1964). 87 E.g., F. Sorauf, Polmical Parties in the American System 2-6 (1964). 
The election would result in a wide fragmentation of the vote and in the success of an interest group limited in scope and purpose to a single issue. ${ }^{88}$ The role of the political party is to mold a plurality of interests into a more durable coalition. The party could take all voters favoring abortion and ambivalent on gun control and all those favoring gun control and ambivalent on abortion and nominate a candidate favoring gun control and abortion. If the same candidate opposes defense spending, all those who oppose defense spending and are ambivalent as to the other two issues will join the coalition.

It is obvious that when the voters are concerned with more than a single issue potential conflicts arise. A voter who opposes defense spending but favors abortion would be undecided whether or not to join the coalition. But by giving to each member of the coalition something that he considers important, while requiring a concession on issues of lesser importance, the party can retain the voter in its coalition. The more things that a party is able to deliver to various members of its coalition-legislation, patronage jobs, social welfare, ethnic recognition in candidate selection-the more successful the party can be in perpetuating its coalition and remaining in power. Since the goal of the party is to gain and retain control of the government, it does not look to the quick fulfillment of a policy objective at the expense of its governing coalition. Thus a party will not adopt an antiabortion bill if the result would be to destroy its coalition irreparably. A "Right to Life Group" would not hesitate to do so even if it meant its certain defeat at the polls; the passage of the bill would fulfill its goal and attaining power is merely a step toward that end.

The long term concerns of the party result in increasing both societal stability and governmental stability. The inherent conflicts are minimized by the party in order to avoid fragmentation of the coalitions. The success of the parties in maintaining their coalitions limits the number of groups competing at the electoral level..$^{89}$ Since it is easier to enlarge the coalition by adding groups on the border between the parties rather than restructuring the coalitions entirely, parties tend to compete for similar groups, thereby minimizing differences on issues of great potential divisiveness. The desire to perpetuate the

88 In The Federilist No. 10, Madison expressed the view that a "faction" taking control of the government endangers liberty. He argued that this could be avoided by creating a system with a sufficient plurality of interests to check the concentration of power in a single faction. A leading commentator contends that the political party serves as the antidote to factionalism by subordinating the demands of each pressure group to the success of the party. E.E. SchatTschneIder, PARTY GovernMENT 6-16 (1942).

80 See, e.g., E. Banfield, In Defense of the American Party System, in Polrtical Parties, U.S.A. 21-39 (R. Goldwin ed. 1964). 
existing coalition forces the party to try to meet the expectations of its members, creating a sense of party responsibility. The result is generally to allow voters to predict what a party will do in office better than they can predict what actions an individual elected by a more temporary alliance will take.90

To the extent that the interests of the coalition reflect consistent policy positions, competing parties develop political ideologies. If a party has advocated federal aid to education, it is likely that advocating federal health insurance will cause less resistance among the members of its coalition than taking the opposite position. It is likely, therefore, that maintaining an ideologically consistent policy will add more members to the coalition with fewer defections. In fact, there is little doubt that voters do associate the parties with distinct policy positions and that on issues of substantial importance those perceptions are reflected by the voters. ${ }^{91}$ Elections are often decided by those voters not a part of the coalition of any party or those members of the coalition whose connection is sufficiently tenuous to cause them to defect as a result of the party taking positions of which they do not approve.

As part of the functions of creating the coalitions, the parties perform auxiliary functions of great value to the political system. As the instrument of candidate recruitment and voter mobilization, political parties finance campaigns and play crucial roles in political education and socialization. ${ }^{92}$ The parties operate alongside the mass media in organizing knowledge about American politics. The conflicting claims of the parties inform the voters concerning issues of importance, and simplify a complexity of arguments so as to make the competing positions comprehensible to the less sophisticated voter. The parties articulate interests and relate a set of values to a policy or candidate alternative faced by the voter. Moreover, the parties can play an important

90 There is a substantial amount of opinion that parties should be more centralized and exert stricter discipline over its elected candidates. This would result in elected officials taking action more closely related to that advocated in their campaigns and in more ideologically oriented parties. See, e.g., Committee on Political Parties of the American Political Science Ass'n, Toward A More Responsible Two Party System, 44 AM. PoL. Sar. REv. (Supplement to Sept. issue, 1950). It has been argued, however, that this would adversely affect the ability of the parties to create coalitions and to reconcile conflicting interests. See, e.g., E. BANFIELD, supra note 89; Kirkpatrick, Toward a More Responsible Two-Party System: Political Science, Policy Science or Pseudo-Science?, 65 AM. Por. Scr. REv. 965 (1971); Turner, Responsible Parties: A Dissent from the Floor, 45 AMr. PoL. Sar. REv. 143 (1951).

91 See, e.g., Pomper, From Confusion to Glarity: Issues and American Voters 1956-68, 66 Am. Por. Scr. Rev. 415 (1972); RePass, Issue Salience and Party Choice, 65 Am. Por. Scr. Rev. 389 (1971). But see A. Camprell, P. Converse, W. Mirler, \& D. Stokes, The AMERICAN VOTER (1960). For a nearly comprehensive listing of recent studies on this question, see Kessel, Comment: The Issues in Issue Voting, 66 AM. Por. Scr. Rev. 459 n.l (1972).

92 See generally F. SORAuF, supra note 87. 
role in integrating divergent and alienated groups into the political and social system..$^{3}$

If judicial decisions were to prevent the political party from taking steps to select its nominees prior to primary elections, rather than simply organizing conventions or preprimaries, the result would be a fragmentation of the coalition. The party would cease to function if victory in the primary would no longer include an automatic claim to the support of the preexisting coalition, since, if the party cannot select or control its nominees, then it cannot deliver on the promises made to the members of the coalition, and the party would lose its means of creating and maintaining its coalition. As a result, candidates representing the interest groups would have to create their own coalitions, which would be more ad hoc and temporary in nature. ${ }^{94}$ The parties would, to some degree, be incapable of performing those functions generally attributed to them. Instead, those functions would have to be performed by other groups, more temporary and often less capable of doing so. The recruitment and mobilization functions would be undertaken by ad hoc groups concerned with a single candidate or single issue. The candidates would be likely to have an independent basis of support and would have to have large amounts of private money at their disposal to be successful. The aggregation and coalescing of interests would be done on a less permanent basis and probably at the governmental level itself with a consequent increase in instability. Furthermore, it seems likely that many of the functions political parties perform between elections would, of necessity, be taken over by other institutions, most probably the government, much in the same way that the decline of the urban political machines thrust much of the task of public welfare on the government bureaucracy. ${ }^{95}$

Given this perspective on the American party system, a reexamination of the crossover primary decisions is in order. In holding that the state legislatures may not hold restrictive closed primaries, the courts

93 The role played by the urban political machines in providing access into the political and socioeconomic systems for the immigrant groups in the first quarter of the twentieth century is an important contribution of the parties. E. Banfreld \& J. Wilson, Crty PoliTICS 38-44 (1963).

94 One commentator has suggested that the coalitions that would arise would closely resemble those that the parties create, since the candidates would seek to maximize votes much as the parties do. A. Downs, AN Economic Theory of Democracy (1957). That argument, however, assumes a linear spectrum of interest (like a liberal-conservative axis), in which only a very limited number of coalitions are feasible. It seems likely that the fragmentation of interests is, in fact, much greater and only through the long term operation of a party and the large number of potential benefits available to a party for distribution to coalition members can a more permanent coalition be established. See E.E. SCHATTSCHNEIDER, supra note 88 , at 28-34.

95 E. BANFIELd \& J. Wilson, supra note 93 , at $330-46$. 
may well have failed to understand the true nature of a primary as an intracoalitional event and may be forcing the party to make its nominations in a preprimary convention. If the courts successfully open the nominating process to all voters without regard to party affiliation the price may well be the decline of strong competitive parties.

In this light, the Supreme Court's decision in Williams v. Rhodes ${ }^{96}$ can be viewed as an underpinning for judicial decisions finding crossover restrictions permissible rather than as a basis for invalidating them. ${ }^{97}$ In Williams, the Court expanded access to the ballot in general elections, recognizing that parties create coalitions offering policy alternatives. The decision serves to facilitate the formation of new parties to contest the elections. But it does not shift the focus of the general political struggle to the primary. Instead, it leaves the primary as an intrapartisan event in which the respective coalitions of the party can work out the proper conciliations of their own interests and then face the electorate offering a coherent policy alternative. In fact, to the extent that the decision increases the policy alternatives competing in the general election, it makes interference in primary operations unnecessary. Williams can be read as establishing a constitutional right for a substantial group of voters-a "significant modicum," in the Jenness v. Fortson ${ }^{98}$ terminology - to raise an issue crucial to them in a serious way among the electorate.

Primaries, however, have tended to be an improper forum for raising such issues in the American political system. ${ }^{99}$ Williams not only permits the parties to continue to perform their functions of coalition and aggregation, but encourages each party to perform those functions more effectively, by sufficiently conciliating the interests advanced by the challengers with its own in order to avoid electoral competition. Justice Black, in Williams, found the constitutional infirmity to be the advantage given to the current Democratic and Republican nominees over those of other parties, not the preferred position given to party nominees over potential independent candidates. ${ }^{100}$ Thus, the right guaranteed by Williams is the right of a new party to emerge when the old ones fail in their performance or when the grievance of the group is so fundamental as to be irreconcilable with the existing parties.

If the existing parties fail to bring emerging parties into their coalitions, the result under Williams is a multiplicity of parties competing in

96393 U.S. 23 (1968).

97 But see Barton, The General Election Ballot: More Nominees or More Representative Nominees?, 22 Stan. L. REv. 165 (1970).

98403 U.S. 431 (1971).

99 See note 84 supra.

100393 U.S. at 32. 
the general election. In the absence of a runoff election, the possibility of a minority candidate being successful is significant, and the incentive for the proliferation of parties is increased. Hence, the increased ballot access enhances the likelihood of coalition fragmentation. Given this prospect, it becomes imperative that political parties that are capable of retaining the elements of their coalitions not be hampered in their efforts to do so. The reduction of control in candidate selection and interest conciliation that results from the relaxing of crossover restrictions becomes an even more critical danger in this context.

Even for the newly emerging parties the restrictions on crossovers may be extremely crucial. If party $Y$ is created by a dissident group formerly belonging to party $X$, allowing members of party $X$ to cross over and select the nominees of party $Y$ may serve to kill the emerging party. The ability to select its own candidates and to form its own coalition by appealing to a variety of interests may be an absolute prerequisite to the emergence of the new group as a viable political party.

The ideal situation may be to give to each party the power to determine eligibility to participate in its own primary. While crossover voting restrictions protect the strength and autonomy of political parties, they may be accompanied by offsetting disadvantages. A party may find that, although allowing crossovers would increase the danger that the party would lose control of its candidate recruitment process, this danger is outweighed by the gains in voter recruitment, recognition of potential additions to its coalition, and increased enthusiasm among its supporters that might result from allowing broader participation in its nominating procedures. There seems to be no reason why each party should not be allowed to make its own calculus regarding the impact of crossovers, and to determine the optimum way in which to perform its functions with respect to its ultimate goal of vote maximization. The right of political association should require these decisions to be made by each party. The government is prohibited from impairing the organization of a group seeking to nominate a candidate. Requiring a group to open its doors to all comers dilutes the effectiveness of the group and serves the same result as prohibiting their organization in the first place. If the result of crossovers is that John Connally is the nominee of the Raza Unida Party or James Eastland of the Mississippi Freedom Democrats, the party is no better off than it would have been had the state expressly prohibited its organization.

\section{CoNCLUSION}

Whether the rules regarding eligibility are established by the state or by the parties, there are some restrictions on primary participation 
that should not be allowed to stand. It may be contended that all restrictions on primary participation should be sustained, on the ground that if parties attempt to maximize votes they will not arbitrarily discriminate against any group. If one party did so discriminate, another would appeal to that same group trying to add it to its coalition. But the experience of the post-Reconstruction South indicates that parties may attempt to exclude a group from political participation even at the price of electoral success; indeed, there may also be situations in which party discrimination against certain groups serves as a tactic of vote maximization. While a party cannot be forced by legislation to try to bring a specific group into its coalition, it is reasonable to prohibit discrimination by a party with respect to eligibility to participate in its nominating process. Such discrimination is, however, very different from crossover limitations, since it is unrelated to the prevention of raiding and party strength and is more clearly invidious in nature. It is a perfectly tenable constitutional position to permit the states or the political parties themselves to protect party integrity by placing time restrictions on crossovers, provided the restrictions are neutral in nature and application, and, at the same time, to prohibit any other restriction on primary participation, finding no sufficient state interest to justify it.

Glen S. Lewy 